\section{P-65表在性膀胱癌に対するBCG膀胱内注入癔法 について}

小畠病院 泌尿器科 11

広島大学 医学部 泌尿器科学教室 2

一田耕司 ${ }^{1)}$ 安川明廣 ${ }^{\prime}$ 碓井 亞 2 ?

【日的】TURなどで治療困難な多発性の表在性膀胱癌（Ta、T1） ならびに上皮内癌（CIS）に対し、BCG膀脱内注入療法を行い、 抗腄揘効果、再発について検討した。对象】1993年から1998年ま での6年間に経験した19例（男14、女5）で、年齢は55歳９0歳、 平均72.6藏であった。病期はCIS：5例、Ta：10例、T1：4例で分化 度はG1：4例、G2：7例、G3：8例であった。また、新鮮例：6例、 再発例：13例であった。【j法】BCG80mgを生食水40mlに溶解後、 膀胱内に注人し30分間貯留し、これを週1回合計6回行い、膀胱鏡 㧍よび层細胞診にて抗腫瘍效果の判定を行った。無再発率は Kaplan-Meier法で算出した。結果】19例のうちCR：14例、PR：3 例、NC：2例であった。CRが得られた14例の無再発率は1年後、3 年後ともに71.4\%（10例）であった。CRで1年以内に再発を認めた 1 例は浸潤癌となり死亡、NCの2例は浸潤癌となり膀胱全摘除術 を受けた。副作用は膀胱刺激症状13例、発熱（37.5度以上）2例、 萎綰膀胱が1例であった。総括】BCG膀脱内注入療法が表在性膀 脱游に対し有効な治䝤法である一方、膀注が無効な症例、1年以 内に再発する症例には浸潤癌が発生する可能性が示唆される。

表在性膀胱癌 BCG 膀胱内注入療法

\section{P- 67 当院におけるBCG膀胱内注入療法による表 在性膀胱癌の治療成績}

\section{聖隷三方原病院 泌尿器科 ${ }^{1}$ 浜松医科大学 泌尿器科 ${ }^{2}$}

永汇浩史 ${ }^{1}$ 永田 鈴木和雄 ${ }^{2}$ 藤田 公生 ${ }^{2}$

【日的】膀脱上皮内嵒 (CIS) および経尿道的腫瘍切除術 (TUR-Bt) にて治撚切除が得られなかった表在性膀胱癌症例に対してBCG膀 胱内注入潦法を施行しその有用性について検討した。【対象と方 法】1997年2月から1999年9月までに当院でBCG膀胱内注入療法を 施行した表在性膀胱癌23例（男20例、女3例、年齢45－80歳、平均 65.4瓷）対象とした。对象病变はCIS力5 5例（初発/再発 2例/3例）、 TURによる 将変 $(\mathrm{Ta}+\mathrm{T} 1$ 、初発/再発 13例/5例、G1/G2/G32例/2例 /14例）切除後の切除縁粘膜および無作為生検により腫瘍残存ある いはTisが認められた症例が18例である。BCG投与法は、1回40 $\mathrm{mg}$ で1週間毎合計6[回を原則とした。BCG投与終了後の尿細胞診と無 作為生検により治潦効果を判定した。【結果】CISでは5例中4例 (80\%)、TUR-Bt非根治例では18例中13例（72\%）に佂いてCRを得 た。このうちCISの1例（26\%月）およびTUR-Bt非根治例の2例 (13ヶ月、14ヶ月) に再発を認めた。治療期間中の副作用は、膀胱 刺激症状 8 例 $(34 \%)$ 、血尿5例 $(21 \%)$ 、発熱1例 $(4 \%)$ で重篤なも のはなかった【結棆】CIS㧍よび TUR-Bt非根治例に対するBCG膀 胱内注人潦法は、近接效果に優れていたが、今後長期的観察によ る検䣓を要すると考えられた。

表在性膀胱癌 BCG 膀胱温存

\section{P- 66 表在性䏽胱茜に対するBCG膀胱内注入凊法 による再発予防効果の臨床的検討}

\begin{abstract}
倉敷成人病センター1) あらき腎・泌尿器科クリニック
塩塚洋一1)佐古真一1)国冨公人1)石户則孝1 高本均11 荒木 徹 ${ }^{2)}$

【目的】表在性膀胱癌に対するBCG膀胱注入療法の再発予防效果 を、BCGの注入量，注入回数、腫瘍性状等について検討した。 【対象と方法】対象は1987年8月から1997年12月までにTUR-Bt後に 再発予防目的でBCG注入療法を開始した表在性膀胱癌70例（男58, 女12)、年齢41 89歳 (平均65.4藏)、経過観察期間 6 123\%月 (中央值28ヶ月）である。BCG注入法は80mgまたは40mgを生食 $40 \mathrm{ml}$ に懸濁し、1 週毎 6 回後、1 月月毎 4 回の計 10 回注.入を目標 とした。またTUR-Bt直後のEPI-ADM50mg（生食500 mll溶解）の 膀胱内海流とBCG注入時抗結核剛の併用を全例に施行した。【結 果】BCG注入量は $80 \mathrm{mg}$ 群と40mg群で再発率に差はなかったが、 $80 \mathrm{mg}$ 群で副作用が多い傾向にあった。注入回数は10间以上群が 9 回以下群に比べ有意に再発率が低かった。腫瘍の性状では多発群 が単発群に比べ有意に再発率が高く、Grade別は10回以上注入群で Grade 3 群がGrade 1 - 2 群に比べ有意に再発率が高かった。腫場 径、Stage別では再発率に差を認めなかった。結語】再発予防目 的のBCG膀胱内注入潦法は40 mgt 10 回以.1:行うのが良い。多発例、 Grade3例は再発率が高く、治療法の再検討が必要と思われた。
\end{abstract}

表在性膀胱瘦 BCG

\section{P-68 回腸利用勝胱扩大術モデルラットにおける 腸上皮細胞のNa輸送能の变化}

\begin{abstract}
神戸大学 医学部 泌尿器科 ${ }^{1)}$ 鐘紡記念病院 ${ }^{2)}$
酒井豊1) 藤澤正人 1) 中野雄造 ${ }^{2}$ 吉行一馬1) 米本洋次1)

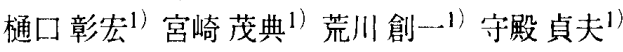

【日的】腸管を利用した尿路再建術後には腸上皮からの再吸収に よりしばしば高Cl性アシドーシス、尿 $\mathrm{pH}$ の上昇を認める。しかし 術後経時的に血中C濃度、尿 $\mathrm{pH}$ 值は低下する。そこで今回我々は 回腸利用膀胱拡大術モデルラットを用いて尿路再建に用いられた 腸上皮細胞のNa輸送能の変化について検討した。【方法】SDラッ 卜、雌、8週齢を用いて回腸利用膀胱拡大術モデルを作成、術後3 カ月および12力月時に本来の回腸と尿路再建に用いた回腸部分を 摘出し腸上皮細胞を得た。Pluronic F-127: DMSO、SBFI-AMを添加 したGlucose含乳酸リンゲル液中にて $37 \mathrm{C} 、 1$ 時間放置後、Na非芌 有等張液中に4C、6時間放置し腸上皮細胞を精製、営光吸光度光 度計を使用し、腸上皮細胞に $50 \mathrm{mM} \mathrm{Na}$ 加え、340nmおよび $380 \mathrm{~nm}$ の波長光を $2 \mathrm{~Hz}$ 照射した際に生じる510nmの励起を測定した。 【結果】通常の回腸上皮細胞の340/380nm比は $0.85+0.09$ (mean + SD) であったのに比し、術後3力月の尿路の腸上皮緗胞では $0.73+0.15$ 、 12力月では0.49+0.23 と隇少傾向にあり、12力月では有意に減少し ていた。【結語】尿路再建術後の再吸収の変化の要因の一つとし て腸上皮細胞のNa吸収能の変化が関与している可能性が示唆され た。
\end{abstract}

尿路变向 $\mathrm{Na}$ 輸送能 